tyres and five radial tyres on four different wet road surfaces. Of the two groups, radials were slightly the better, but within each group the differences attributable to tyre tread and material are less than the scatter of the experiment. Only one type, an Italian tyre not recommended for British roads, was significantly worse than the rest. The generally better performance of the radials, Mr Meades concludes, is consistent with the view that they are better at removing water from the contact region; at 80 m.p.h. on polished concrete the peak braking coefficient for radials was $0 \cdot 6$, while that for cross ply tyres was $0 \cdot 5$.

The experiments also showed that when the wheels lock, braking coefficients are frequently reduced by a factor of two or three, and occasionally by as much as eight. Drivers are therefore in danger of over-estimating the braking power available to them. Automatic braking devices which prevent the wheels from locking offer a chance of making the best use of the friction availab'e. Perhaps more important, though, is the need to retain directional control, which is almost completely lost when the wheels lock. Skidding, the laboratory estimates, is involved in about 70,000 accidents each year; 33 per cent of all accidents in wet conditions involve skidding.

Several systems of automatic brake control have been announced. The Dunlop Maxaret system uses a rubber tyred wheel driven by the road wheel which it controls. Within the driven wheel is a flywheel kept in driving contact by a spring; normally the flywheel rotates at the same speed as the driven wheel, but when brakes are applied and the driven wheel deceleratcs, the flywheel continues to rotate against the resistance of the spring and operates valves which release the brakes. The driven wheel then accelerates again, catches up with the flywheel, and the brakes are reapplied. Experiments almost ten years ago at the RRL by R. D. Lister and R. D. Kemp showed that units of this type can reduce braking distances and give much better control during braking.

Lockheed have also produced a system of control, called the Lockhecd Antilock. This operates on the rear wheels only, and uses an inertial system driven from the propeller shaft to prevent the rear wheels locking. The system has demonstrated that braking distances ean be reduced and directional stability maintained. Another system, the Kerr Antilocking device, makes use of the forces produced in the suspension of the vehicle to release the brakes when the wheels begin to slip. Yet another, the Autostable braking system, makes use of torque reactions on the front brakc shoes to regulate the pressure to the rear shoes.

Although several of these systems have been convineingly demonstrated, their use is still very restricted. The Dunlop Maxaret system, used on aircraft, has been fitted to some commercial articulated vehicles, at a cost of $£ 150$ per axle converted. Cost may well be more significant than technical factors, and it is probable that antilock devices will not achieve widespread acceptance until their use is compelled by legislation.

\section{Keeping Armies in Touch}

Brrtars has joined the United States, Australia and Canada in a collaborative project to develop a tactical trunk communications system for their armed forces.
The United States, Canada and Australia ratified an agreement to proceed with the project, called Mallard, in April of this year, but Britain deferred a decision because the problem of the sharing of costs and work had not been resolved. The project will cost about $£ 45$ million over 8 years in research and development, of which the United States will pay about 60 per cent, Britain about 30 per cent and Australia and Canada about 10 per cent. When the scheme goes into operation towards the end of the seventies, it is expected to cost between $£ 200$ million and $£ 350$ million. Each country will have the right to place contracts for up to one-half of its production requirements where it wishes, but the balance will be open to competitive tendering.

The Mallard system is a development of the British "Hobart Plan" for a digital tactical communications system. The United States authorities considered that this sort of system could not be developed until the carly eighties instead of the middle seventies, and so had been developing a less sophisticated analogue system. The Mallard system will provide secure, fully automatic, switched communications in the battlefield area from army headquarters down to battalion level and will link up with the "Clansman" system down to forward battle positions. It will also link up with other strategic communications systems including "Skynet", the satellite system. It will have facilities for transmitting and receiving speech, telegraph, data and facsimile, and will replace the "Bruin" systern, a microwave trunk telephone communications system due to come into service next year.

In the initial development phase of the programme, the competitive system design studies will be carried out by United States and British electronics companies. A consortium of GEC, Marconi, Plessey and S'IC, co-ordinated by the Signal Research and Development Establishment, has been formed to do the design studies in Britain. Other companies will be called into the consortium as required, and when the system is developed it is hoped that other countries in NATO will buy it.

\section{EMBO Fellows}

STXTEen long-term fellowship awards for $1967 / 68$ have been announced by the European Molecular Biology Organization. These awards, tenable for a year, allow research workers in molecular biology to attend centres to continue their research. Although the organization is European, it does award fellowships to non-Europeans who wish to work in Europe and to Europeans who wish to work outside Europe.

Among the fellowships awarded, Dr Ch. Phelps, of Bristol, has received one to work on conformational changes and enzyme kinetics at the Istituto di Chimica Biologica, Centro di Biologia Moleculare, Rome; Dr I. Cordone, of Palermo, has received one to work on messenger-ribosome relations at the Laboratory of Genetics of Brussels University; and Dr J. P. Richardson, of Cambridge, Massachusetts, has received one to work on the structure of IRNA polymerase at the Institut de Biologie Moleculaire, Geneva University. EMBO has also renewed the fellowship awards of Dr C. Vesco, at the Department of Biology, MIT; Dr J. Witz, at the Laboratory of Molecular Biology, Cambridge University; Dr E. Pojnar, at the Department 